\begin{tabular}{|l|l|l||}
\hline \multicolumn{2}{|c|}{ PublisherInfo } \\
\hline \hline PublisherName & $:$ & BioMed Central \\
\hline \hline PublisherLocation & $:$ & London \\
\hline \hline PublisherImprintName & $:$ & BioMed Central \\
\hline \hline
\end{tabular}

\title{
BLAST off
}

\begin{tabular}{|l|l|l||}
\hline \multicolumn{2}{|c||}{ ArticleInfo } \\
\hline \hline ArticleID & $:$ & 4390 \\
\hline \hline ArticleDOI & $:$ & 10.1186 /gb-spotlight-20020201-01 \\
\hline \hline ArticleCitationID & $:$ & spotlight-20020201-01 \\
\hline \hline ArticleSequenceNumber & $:$ & 56 \\
\hline \hline ArticleCategory & $:$ & Research news \\
\hline ArticleFirstPage & $:$ & 1 \\
\hline \hline ArticleLastPage & $:$ & 2 \\
\hline \hline & & RegistrationDate : 2002-2-1 \\
\hline ArticleHistory & $:$ & OnlineDate \\
\hline \hline ArticleCopyright & $:$ & BioMed Central Ltd2002-1 \\
\hline \hline ArticleGrants & $:$ & \\
\hline \hline ArticleContext & $:$ & 130593311 \\
\hline \hline
\end{tabular}


Molecular biologists using Apple computers can receive a speed boost if they use an optimized version of BLAST and the new Mac operating system OS X on a Macintosh G4. The new version of BLAST, called A/G BLAST, was engineered by Apple's Advanced Computation Group in conjunction with Genentech and was announced on 29 January at the O'Reilly Bioinformatics Technology Conference in Tucson Arizona. A/G BLAST is optimized to take advantage of the G4 processor's Altivec or 'Velocity Engine' components to substantially increase the speed and efficiency of running BLAST queries.

A/G BLAST outperformed BLAST dramatically in a test case of a homology search of mouse chromosome 16 against human chromosome 21 using the NCBI word size of 11 nucleotides. The optimized BLAST required only 45 minutes, compared to NCBI-BLAST on the same machine, which took over four hours.

Steve Jobs, iCEO of Apple, recently announced that Genentech were the first customers for the G4 iMac, having placed a pre-order for 1000 machines. The optimized software is available for immediate download either as source code or executable, from the Apple Advanced Computation Groupwebsite.

\section{References}

1. O'Reilly Bioinformatics Technology Conference, [http://www.oreillynet.com/biocon2002/]

2. NCBI-BLAST, [http://www.ncbi.nlm.nih.gov/BLAST/]

3. Apple Advanced Computation Group, [http://developer.apple.com/hardware/ve/acgresearch.html] 